\title{
An atypical Toxoplasma gondii genotype in a rural Brazilian dog co-infected with Leishmania (Viannia) braziliensis
}

\author{
Rodrigo Costa da Silva ${ }^{[1]}$, Karen Caffaro ${ }^{[2]}$, Carolina Lechinski Paula ${ }^{[2]}$, \\ Rafaela Mastrangelo Risseti ${ }^{[2]}$, Helio Langoni ${ }^{[2]}$, Jane Megid ${ }^{[2],}$ \\ Mariana Serrano Melanchauski ${ }^{[3]}$, Katiane Lohn Souza ${ }^{[3]}$, Regina Kiomi Takahira ${ }^{[3]}$ \\ and Vânia Maria de Vasconcelos Machado ${ }^{[4]}$
}

[1]. Department of Pathobiology and Population Medicine, College of Veterinary Medicine, Mississippi State University, Mississippi State, USA. [2]. Departamento de Higiene Veterinária e Saúde Pública, Faculdade de Medicina Veterinária e Zootecnia, Universidade Estadual Paulista, Botucatu, São Paulo, Brasil. [3]. Departamento de Clínica Veterinária, Faculdade de Medicina Veterinária e Zootecnia, Universidade Estadual Paulista, Botucatu, São Paulo, Brasil. [4]. Departamento de Reprodução Animal e Radiologia Veterinária, Faculdade de Medicina Veterinária e Zootecnia, Universidade Estadual Paulista, Botucatu, São Paulo, Brasil

\begin{abstract}
Toxoplasmosis and leishmaniasis are two worldwide zoonoses caused by the protozoan parasites Toxoplasma gondii and Leishmania spp., respectively. This report describes the clinical and laboratorial findings of a co-infection with both parasites in a 4-year-old female dog suspected of ehrlichiosis that presented anemia, thrombocytopenia, hypoalbuminemia, hyperglobulinemia, tachyzoite-like structures to the lung imprints, and polymerase chain reaction (PCR) results positive for T. gondii (kidney, lung, and liver) and Leishmania spp. Co-infection with Toxoplasma gondii and Leishmania braziliensis was confirmed by sequencing; restriction fragment length polymorphism-polymerase chain reaction (RFLP-PCR) confirmed an atypical T. gondii genotype circulating in dogs that has been reported to cause human congenital toxoplasmosis.
\end{abstract}

Keywords: Immunosuppression. American visceral leishmaniasis. Toxoplasmosis.

\section{INTRODUCTION}

Toxoplasmosis is a worldwide anthropozoonosis caused by a coccidian protozoan, Toxoplasma gondii. Felids are the definitive hosts, while most warm-blooded animals are intermediate hosts ${ }^{(1)}$. Dogs are considered sentinels for human infection; they are infected by ingesting raw or poorly cooked meat containing tissue cysts and by ingesting sporulated oocysts present in the contaminated feces of cats $^{(2)(3)(4)}$.

Leishmaniasis is a zoonotic disease caused by Leishmania spp., and manifested in South America as American visceral leishmaniasis (AVL, Leishmania infantum chagasi) and American tegumentary leishmaniasis (ATL, mainly Leishmania braziliensis $)^{(1)}$. L. braziliensis can cause visceral disease as a consequence of host immunosuppression, and is considered an opportunistic disease transmitted by phlebotomine bites after blood feeding from infected dogs, the main urban reservoir.

Corresponding author: Dra. Jane Megid. Depto. de Higiene Veterinária e Saúde Pública/FMVZ/UNESP. Distrito de Rubião Júnior s/n, 18618-970 Botucatu, São Paulo, Brasil.

Phone: 5514 3880-2103; Fax: 5514 3880-2042

e-mail: jane@fmvz.unesp.br

Received 19 November 2014

Accepted 24 February 2015
Hence, we report a T. gondii and L. braziliensis co-infection in a Brazilian dog suspected to have an Ehrlichia canis infection, and an atypical $T$. gondii genotype circulating in dogs.

\section{CASE REPORT}

A mixed breed female dog weighing $15.3 \mathrm{~kg}$ and approximately 4 years of age from the rural area of Botucatu, SP, Brazil (22 $53^{\prime} 08^{\prime \prime}$ 'S $48^{\circ} 26^{\prime} 42^{\prime \prime} \mathrm{W}$ ) was brought to the Veterinary Hospital, School of Veterinary Medicine and Animal Science [Faculdade de Medicina Veterinária e Zootecnia (FMVZ)], São Paulo State University [Universidade Estadual Paulista (UNESP)] in May 2013. The animal had a previous history of fever and apathy starting 1 year prior. During that time, the animal was examined at a private veterinary clinic, clinically diagnosed, and treated for ehrlichiosis. One year later, the animal presented hyporexia, diarrhea with mucous, tachypnea, a reactive left submandibular lymph node, rectal temperature of $39.9^{\circ} \mathrm{C}$, and was suspected to have bronchopneumonia.

Blood samples were collected for a complete blood cell count, serum biochemical analyses, and testing for $T$. gondii, Neospora caninum, and Leishmania spp. antibodies by the indirect fluorescent antibody test (IFAT) method. The IFAT was assayed with antigens produced in-house (tachyzoites of T. gondii, RH strain; tachyzoites of $N$. caninum, NC-1 strain; 
and promastigotes of Leishmania major, MHOM/SU/1973/ 5 -ASKH); the cut-off titers were 16,40 , and 50 , respectively. IFAT was carried out using a goat anti-dog immunoglobulin $\mathrm{G}$ [IgG (H\&L)] commercial conjugate (A40-123F; Bethyl Laboratories Inc., Montgomery, TX, USA). The serology results were positive for N. caninum (titer 100) and T. gondii (titer 16), but negative for Leishmania spp.

In addition, the animal presented pulmonary fields with diffuse opacification on a thoracic radiographic image with bronchial, interstitial, and alveolar patterns, and enlargement of the bronchial wall, suggesting bronchopneumonia. The heart presented a discrete hogback with respect to the right atrium. Three days later, the previous findings had worsened with accentuated diffuse opacification. The heart limits of the right atrium and pulmonary trunk were still curved. After 3 days, impairment was observed with a mixed pattern that tended to be micronodular in structure, suggestive of a fungal infection.

An erythrogram demonstrated normocytic normochromic anemia [mean corpuscular volume $(\mathrm{MCV})=70.5 \%$; mean corpuscular hemoglobin concentration $(\mathrm{MCHC})=33.1 \%$ ) and thrombocytopenia $\left(28,000\right.$ platelets $\left./ \mu \mathrm{L}^{-1}\right)$ (Table 1); lymphopenia $(290 \mathrm{cells} / \mu \mathrm{L})$ and eosinopenia $(0.0$ cells $/ \mu \mathrm{L})$ were observed on a leukogram; and hypoalbuminemia $(1.5 \mathrm{~g} / \mathrm{dL})$ and hyperglobulinemia $(5.1 \mathrm{~g} / \mathrm{dL})$ were found in the biochemical analyses ${ }^{(5)}$. Rouleaux was still observed. Chloramphenicol sodium succinate $(50 \mathrm{mg} / \mathrm{kg}$ three times a day; Ariston, São Paulo, SP, Brazil) was used to treat the ehrlichiosis and bronchopneumonia. Furosemide $(4 \mathrm{mg} / \mathrm{kg}$ twice a day; Sanofi, São Paulo, SP, Brazil), bromhexine $(3 \mathrm{mg} / \mathrm{kg}$ once a day, Boehringer-Ingelheim, São Paulo, SP, Brazil), and oxygen therapy were used for pulmonary complications; fluid therapy with lactated Ringer's solution plus glucose for dehydration; and a multivitamin $\left(5 \mathrm{~mL}\right.$ twice a day, Clusivol ${ }^{\circledR}$; Wyeth Consumer, São Paulo, SP, Brazil) to stimulate the appetite. The animal died 10 days later, and pneumonia associated with renal and hepatic lesions was confirmed by necropsy. Lung, kidney, and liver samples were finely chopped, imprinted in slides, and stained with Giemsa; they showed negative results for Ehrlichia spp., but presented tachyzoite-like structures in the lung tissue.

The samples were tested for $T$. gondii ${ }^{(6)}, N$. caninum $^{(7)}$, E. canis $^{(8)}$, and Leishmania spp. deoxyribonucleic acid (DNA) ${ }^{(9)}$ by the PCR (Table 2). Positive results for T. gondii were observed in the lung, kidney, and liver samples; Leishmania spp. was found in the lung and liver. All samples yielded negative results for $E$. canis, $N$. caninum, and L. infantum chagasi.

Samples positive for Leishmania spp. were typed by restriction fragment length polymorphism-polymerase chain reaction (RFLP-PCR) using one marker for species identification and the restriction enzyme HaeIII ${ }^{(9)}$, and showed L. braziliensis. In the same way, samples positive for $T$. gondii were also typed by RFLP-PCR using 11 markers for genotype identification ${ }^{(10)}$. All three tissue samples were confirmed to contain $T$. gondii by genotyping, and demonstrated an atypical genotype (Table 3) reported in the scientific literature to cause human congenital toxoplasmosis, $\operatorname{TgCTBr} 5^{(4)}$. All amplifications were performed in a MasterCycler ep gradient (Eppendorf, USA). Sequencing of the purified PCR products (Tg18s58F and Tg18s348R for T. gondii; LITSR and L5.8S for Leishmania spp.) was performed, and the results searched in the National Center for Biotechnology Information (NCBI) GenBank database using the Basic Local Alignment Search Tool (BLAST). All T. gondii and Leishmania spp. products matched the T. gondii $18 \mathrm{~S}$ ribosomal ribonucleic acid (rRNA) gene [L37415.1] and L. braziliensis kinetoplast minicircle gene [EU370877.1], respectively.

TABLE 1 - The hematological and biochemical parameters of the dog sent to FMVZ-UNESP Veterinary Hospital*.

\begin{tabular}{|c|c|c|c|c|c|}
\hline \multirow{2}{*}{$\frac{\text { Hematological parameters }}{\text { Erythrogram }}$} & \multicolumn{2}{|c|}{ Reference } & Leukogram & \multicolumn{2}{|c|}{ Reference } \\
\hline & & & & & \\
\hline Erythrocytes $\left(\times 10^{6} \mu \mathrm{L}^{-1}\right)$ & 3.69 & $5.5-8.5$ & Leukocytes $\left(\times 10^{3} \mu \mathrm{L}^{-1}\right)$ & 9.50 & $6-17$ \\
\hline Hemoglobin $\left(\mathrm{g} / \mathrm{dL}^{-1}\right)$ & 8.6 & $12-18$ & Neutrophils $\left(\times 10^{3} \mu \mathrm{L}^{-1}\right)$ & 8.93 & $3-11.5$ \\
\hline PCV $(\%)$ & 26.0 & $37-55$ & Lymphocytes $\left(\times 10^{3} \mu \mathrm{L}^{-1}\right)$ & 0.29 & $1-4.8$ \\
\hline MCV (fL) & 70.5 & $60-77$ & Eosinophils $\left(\times 10^{3} \mu \mathrm{L}^{-1}\right)$ & 0.00 & $0.15-1.35$ \\
\hline $\mathrm{MCHC}(\%)$ & 33.1 & $32-36$ & Monocytes $\left(\times 10^{3} \mu \mathrm{L}^{-1}\right)$ & 0.29 & $0.1-1.25$ \\
\hline Biochemical parameters & \multicolumn{2}{|c|}{ Reference } & Leukogram & \multicolumn{2}{|c|}{ Reference } \\
\hline \multicolumn{6}{|l|}{ Analyses } \\
\hline Albumin $\left(\mathrm{g} / \mathrm{dL}^{-1}\right)$ & 1.5 & $2.6-3.3$ & $\operatorname{ALT}\left(\mathrm{g} / \mathrm{dL}^{-1}\right)$ & 41.0 & $21.0-73.0$ \\
\hline Serum total protein $\left(\mathrm{g} / \mathrm{dL}^{-1}\right)$ & 6.6 & $5.4-7.1$ & Creatinine $\left(\mathrm{g} / \mathrm{dL}^{-1}\right)$ & 0.6 & $0.5-1.5$ \\
\hline GGT $\left(\mathrm{g} / \mathrm{dL}^{-1}\right)$ & 5.1 & $1.2-6.4$ & Urea $\left(\mathrm{g} / \mathrm{dL}^{-1}\right)$ & 22.0 & $21.4-59.92$ \\
\hline $\operatorname{ALP}\left(\mathrm{g} / \mathrm{dL}^{-1}\right)$ & 123.0 & $20.0-156.0$ & Globulin $\left(\mathrm{g} / \mathrm{dL}^{-1}\right)$ & 5.1 & $2.7-4.4$ \\
\hline
\end{tabular}

FMVZ-UNESP: Faculdade de Medicina Veterinária e Zootecnia - Universidade Estadual Paulista; PCV: packed cell volume; MCV: mean corpuscular volume; MCHC: mean corpuscular hemoglobin concentration; GGT: $\gamma$-glutamyl-transferase; ALP: alkaline phosphatase; ALT: alanine aminotransferase. *Hematological and biochemical reference parameters for healthy dogs (Feldman et al., 2000). 
TABLE 2 - The set of primers used in the present case report.

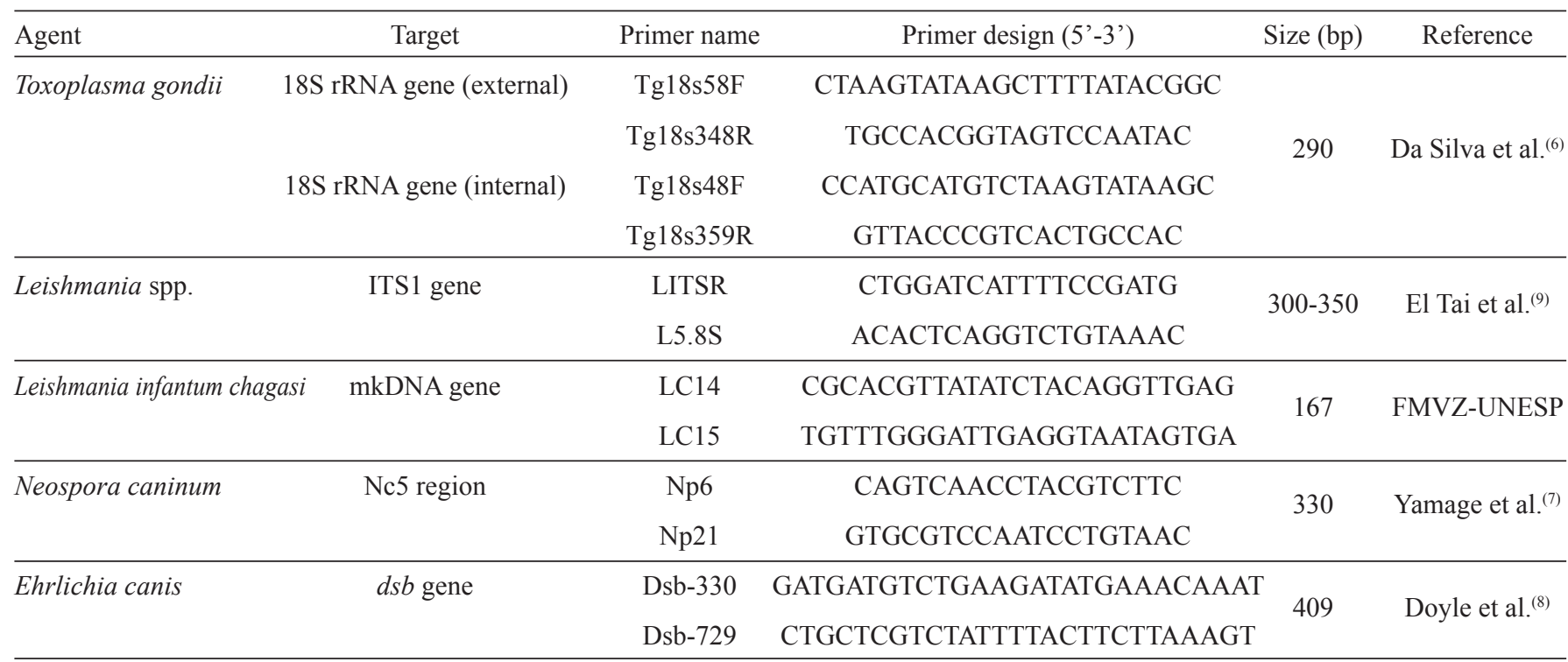

rRNA: ribossomal RNA; ITS: Internal Transcribed spacer; mkDNA: minicircle kinetoplast DNA; Nc: Neospora caninum; Bp: base pair; FMVZ-UNESP: Faculdade de Medicina Veterinária e Zootecnia - Universidade Estadual Paulista.

TABLE 3 - Genotypic profiles of the Toxoplasma gondii samples from the dog tissues.

\begin{tabular}{lccccccccccccc}
\hline & \multicolumn{10}{c}{ Genetic markers } & 11 & \\
Samples & SAG1 & 5'-3'SAG2 & alt-SAG2 & SAG3 & $\beta$-TUB & GRA6 & c22-8 & c29-2 & L358 & PK1 & Apico & Genotype & Reference \\
\hline Lung & I & III & III & III & III & III & I & I & I & u-1 & I & TgCTBr5 & Carneiro et al. ${ }^{(11)}$ \\
Kidney & I & III & III & III & III & III & I & I & I & u-1 & I & TgCTBr5 & Carneiro et al. ${ }^{(11)}$ \\
Liver & I & III & III & III & III & III & I & I & I & u-1 & I & TgCTBr5 & Carneiro et al. ${ }^{(11)}$ \\
\hline
\end{tabular}

\section{DISCUSSION}

In this study, a dog undergoing routine treatment at the FMVZ-UNESP Veterinary Hospital presented a T. gondii and L. braziliensis co-infection. This type of co-infection has already been reported in Brazil in 17/66 (25.8\%) cats by molecular methods ${ }^{(1)}$, but was caused by $L$. infantum chagasi, not $L$. braziliensis. Both parasites have been reported to be opportunistic. Moretti et al. ${ }^{(2)}$ reported a case of a dog coinfected with $T$. gondii, distemper virus, and ehrlichiosis. Immunosuppressive factors decrease host immunity and cause the rupture of pre-existing cysts, reactivating latent infections $^{(1)(3)(2)}$. In this case, even with a negative result for E. canis, ehrlichiosis was not ruled out because the animal could have been a carrier. Additionally, an atypical T. gondii genotype was identified from the Brazilian dog; curiously, the same genotype has been isolated only in Brazil from cats, chickens, capybaras, sheep, rabbits, and mice, and was recently reported by Carneiro et al. ${ }^{(4)}$ to cause human congenital toxoplasmosis in the State of Minas Gerais, Brazil, but with no clinical signs. The authors reported that it was confirmed as an avirulent genotype, among others, by mouse bioassay. The present study emphasizes the occurrence of this genotype and disease with pulmonary complications probably caused by the opportunistic multiplication of $T$. gondii as a consequence of immunosuppression. Even under these conditions, an avirulent parasite can multiply, infect other hosts, and cause disease. The findings observed by Moretti et al. ${ }^{(2)}$ were similar, but they observed a virulent type I genotype (SAG2 locus) rather than the type III genotype (SAG2 and alt-SAG2 loci) found in this study. This report emphasizes the importance of $T$. gondii, the circulation of the same genotypes in animals and humans, and supports dogs as perfect sentinels for this infection and genotype, as observed in other species.

The hematological, biochemical, and imaging analyses suggested a T. gondii and Leishmania spp. co-infection with an additional immunosuppression factor causing a visceral form of the disease by L. braziliensis. L. braziliensis causes ATL in humans and dogs; however, both here and in the scientific literature, it has been reported to be an opportunistic parasite in immunosuppressed individuals ${ }^{(12)}$.

The low titer for the $T$. gondii antibody findings associated with the hematological, biochemical, and imaging results 
suggests a possible acute infection with a low parasite load producing a low humoral immune response dependent on a cellular response. Alternatively, it could suggest a reactivation of a chronic T. gondii infection caused by any immunosuppressive factor, for example, ehrlichiosis ${ }^{(2)}$; the same was observed for leishmaniasis. Immunosuppression caused by an immunosuppressive factor changed the cutaneous form of leishmaniasis caused by L. braziliensis into a visceral pattern, as observed by Hernandez et al. ${ }^{(12)}$. The positive result from $N$. caninum antibody testing suggests an old infection with a low parasite load.

Thus, this report demonstrates a T. gondii and L. braziliensis co-infection in a dog presumed to have ehrlichiosis and a cutaneous Leishmania species causing a visceral form of the disease, as well as the circulation of the same T. gondii atypical genotype in dog and human populations, causing congenital toxoplasmosis in humans and other domestic animals. These findings highlight the importance of molecular techniques as epidemiological and diagnostic tools and adjuncts to standard tests to determine the causative agent(s), and supports dogs as the perfect sentinel model for this infection.

\section{ACKNOWLEDGMENTS}

We would like to thank São Paulo State University for providing logistical support and all the technicians that helped with the management of the dog in this case.

\section{REFERENCES}

1. Acha P, Szyfres B. Zoonosis y enfermedades transmisibles communes al hombre y a los animals. $3^{\text {rd }}$ ed. Geneva, Switzerland: Organización Panamericana de la Salud; 2003.

2. Moretti LA, Da Silva AV, Ribeiro MG, Paes AC, Langoni H. Toxoplasma gondii genotyping in a dog co-infected with distemper virus and ehrlichiosis rickettsia. Rev Inst Med Trop Sao Paulo 2006; 48:359-363.
3. Oliveira TS, Turchetti AP, Barbosa FBS, Bicalho ALF, Alencar CAD, Paixão TA, et al. Cutaneous toxoplasmosis in an immunosuppressed dog. Arq Bras Med Vet Zootec 2014; 66:797-800.

4. Carneiro AC, Andrade GM, Costa JG, Pinheiro BV, VasconcelosSantos DV, Ferreira AM, et al. Genetic characterization of Toxoplasma gondii revealed highly diverse genotypes for isolates from newborns with congenital toxoplasmosis in southeastern Brazil. J Clin Microbiol 2013; 51:901-907.

5. Feldman BF, Zink1 JG, Jain NC. Schalm's Veterinary Hematology. $5^{\text {th }}$ ed. Philadelphia: Lippincott Williams \& Wilkins; 2000.

6. Da Silva RC, Su C, Langoni H. First identification of Sarcocystis tenella (Railliet, 1886) Moule, 1886 (Protozoa: Apicomplexa) by PCR in naturally infected sheep from Brazil. Vet Parasitol 2009; 165:332-336.

7. Yamage M, Flechtner O, Gottstein B. Neospora caninum: specific oligonucleotide primers for the detection of brain "cyst" DNA of experimentally infected nude mice by the polymerase chain reaction (PCR). J Parasitol 1996; 82:272-279.

8. Doyle CK, Labruna MB, Breitschwerdt EB, Tang YW, Corstvet RE, Hegarty BC, et al. Detection of medically important Ehrlichia by quantitative multicolor TaqMan real-time polymerase chain reaction of the dsb gene. J Mol Diagn 2005; 7:504-510.

9. El Tai NO, El Fari M, Mauricio I, Miles MA, Oskam L, El Safi $\mathrm{SH}$, et al. Leishmania donovani: intraspecific polymorphisms of Sudanese isolates revealed by PCR-based analyses and DNA sequencing. Exp Parasitol 2001; 97:35-44.

10. Su C, Zhang X, Dubey JP. Genotyping of Toxoplasma gondii by multilocus PCR-RFLP markers: a high resolution and simple method for identification of parasites. Int J Parasitol 2006; 36:841-848.

11. Sobrinho LS, Rossi CN, Vides JP, Braga ET, Gomes AA, de Lima VM, et al. Coinfection of Leishmania chagasi with Toxoplasma gondii, Feline Immunodeficiency Virus (FIV) and Feline Leukemia Virus (FeLV) in cats from an endemic area of zoonotic visceral leishmaniasis. Vet Parasitol 2012; 187:302-306.

12. Hernandez D, Rodriguez N, Martinez C, Garcia L, Convit J. Leishmania braziliensis causing visceral leishmaniasis in a patient with human immunodeficiency virus infection, identified with the aid of the polymerase chain reaction. Trans R Soc Trop Med Hyg 1993; 87:627-628. 